\title{
PERANAN PENDIDIKAN AGAMA ISLAM DALAM MENGATASI \\ DEKADENSI MORAL (STUDI KASUS DESA MELATI II KEC. PERBAUNGAN KAB. DELI SERDANG)
}

\author{
Ziyara Marwah', Khairul Azri Nst ${ }^{2}$ \\ Program Studi Sosiologi \\ Fakultas Ilmu Sosial dan Ilmu Politik \\ Universitas Sumatera Utara
}

ziyaaaa18@gmail.com

\begin{abstract}
ABSTRAK
Tujuan penelitian ini adalah untuk mengetahui pelaksanaan dan peranan pendidikan agama Islam ini dalam mengatasi dekadensi moral remaja, serta pengaruhnya terhadap kehidupan masyarakat, untuk mengetahui apa saja penyebab terjadinya kebobrokan akhlak atau moral di kalangan Desa Melati II, untuk mengetahui hambatan apa sajakah yang ditemui dalam pelaksanaan pendidikan agama untuk mengatasi dekadensi moral serta bagaimana penanggulangannya. Penelitian ini dilaksanakan di Kecamatan Perbauangan Kabupaten Deli Serdang. Penelitian ini menggunakan penelitian kualitatif dengan teknik pengumpulan data yaitu observasi, wawacara, angket, dan studi dokumen. Hasil penelitian ini adalah Pendidikan agama dilaksanakan oleh kelompok -kelompok masyarakat yang terdiri dari pengajian kaum bapak, pengajian kaum ibu, dan pengajian remaja yang diadakan seminggu 3 kali di masjid maupun di rumah-rumah, Ada dua faktor penyebab timbulnya dekadensi moral, yaitu Faktor intern yaitu kurangnya kasih sayang ibu bapak terhadap anaknya, suasana rumah tangga yang kurang aman dan minimnya pendidikan agama dalam lingkungan keluarga. Faktor ekstern yaitu pengaruh yang datang dari lingkungan yang kurang baik serta pengaruh kebudayaan asing yang bertentangan dengan norma-norma agama. Mengamalkan ajaran-ajaran agama adalah suatu hal kewajiban bagi umat Islam untuk mendapatkan ketengan dalam hidupnya di dunia dan untuk mencapai kebahagiaan di akhirat. Usaha-usaha yang dilaksanakan dalam menanggulangi dekadensi moral antara lain harus lebih meningkatkan mutu pendidikan agama baik di lingkungan keluarga, sekolah dan masyarakat.
\end{abstract}

Kata Kunci: Pendidikan Agama Islam, Dedikasi Moral 


\section{PENDAHULUAN}

Dewasa ini masyarakat sering dihebohkan oleh masalah dekadensi moral, atau krisis akhlak yang melanda masyarakat, terutama di kota-kota besar yang sedang berkembang dan maju. Dekandensi moral ini menyebabkan rusaknya mental dan banyaknya terdapat penyelewangan di sana sini. Hal ini sudah barang tentu sangat besar kaitannya dengan pendidikan agama, karena pendidikan agama sangat penting artinya dalam usaha meningkatkan kemajuan bangsa dan negara. Maju mundurnya suatu bangsa ditentukan oleh keberhasilan pendidikan, karena itu pembinaan mental dan moral anak sangat penting karena merekalah yang akan menggantikan generasi penting.

Bidang moral dan mental spritual adalah salah satu pendidikan agama, sebab tanpa pendidikan agama kita tidak dapat memperoleh kader pembangunan yang diharapkan dapat melapori usaha-usaha pembangunan tersebut. Pada akhir ini kita banyak menyaksikan peristiwa-peristiwa yang terjadi di sekitar kita di masyarakat pada umumnya, baik kejadian itu yang kita lihat dengan mata kepala, maupun yang kita ketahui melalui radio, surat kabar dan alat-alat komunikasi lainnya yang sifatnya asusila atau kejadian yang amoral sehingga dapat menimbulkan keresahan masyarakat, yang ironisnya sudah barang tentu akan mengganggu keamanan lingkungan.

Hal ini sering terjadi yang ditimbulkan oleh generasi muda, yang pada saat itu mereka sedang mengalami masa perubahan dari masa kanak-kanak ke masa dewasa, maka hidup mereka penuh kegoncangan, mereka berbuat semuanya tanpa mematuhi peraturan, sifat nakal, keras kepala, berlagak, seperti orang dewasa, berambut gondrong, biasa suka kebut-kebutan, berbuat tingkah laku yang asosial dan amoral seperti: morphinis, ganja, minuman keras dan sebagainya serta mengganggu ketentraman masyarakat umum.

Setiap manusia itu ingin ketenangan dalam kehidupan bermasyarakat terutama aman lingkungan, namun demikian, ketenangan dan ketentraman itu tidak akan tercapai tanpa menjalankan pendidikan agama. Demikian pula masalah dekadensi moral ini dapat diatasi apabila pendidikan agama itu dilaksanakan secara intensif, karena untuk menyelamatkan generasi yang akan datang, pembangunan mental harus sangat diperhatikan dan dilaksanakan dengan intensif, 
di samping itu juga kita tidak boleh melupakan anak-anak yang sekarang adalah yang akan melanjutkan generasi yang lebih tua.

Drajat (1982:23) mengatakan “Apabila dalam masyarakat tidak nampak lagi keunggulan moral, dimana sopan santun itu kurang terpelihara, agama dan nilai- nilai pasti tidak terlihat lagi”. Untuk membina masyarakat dan upaya menghindarkan dari kebobrokan moral, khususnya masyarakat Desa Melati II, tidak ada jalan lain kecuali lebih mengintensifkan pendidikan agama, dimulai dari kalangan keluarga dan lingkungan masyarakat.

Pelaksanaan pendidikan agama harus tercermin dan terjadi sekaligus dalam pengalaman, perlakuan dan percontohan dalam hidup di samping latihan dan pengertian-pengertian tentang ajaran-ajaran agama. ${ }^{12}$ Karena melalui pendidikan agama inilah masyarakat dibina dan dididik moral atau akhlaknya serta ditanamkan ajaran-ajaran agama, terutama yang menyangkut masalah ibadah, muamalah dan akhlak, sehingga mereka menjadi tahu, maka tidak sama predikat orang yang tahu dengan orang yang tidak tahu, Allah Swt. berfirman dalam Alquran:

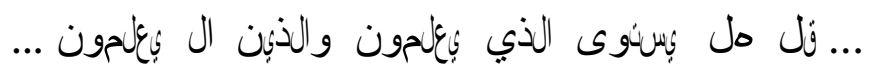

Artinya:

Katakanlah, adakah sama orang yang tahu dengan orang yang tidak tahu dengan orang yang tidak tau. Dept. Agama RI (1985:747)

Rasanya, bergerak maju lebih mengintensifkan pendidikan agama sudah merupakan keharusan bagi kita oleh guru-guru yang melaksanakan pendidikan sebab bersamaan majunya kehidupan yang materialistis di saat sekarang ini, dapat mengatasi corak kehidupan yang menimpa masyarakat yang timbulnya kemiskinan, kekeringan jiwa dan dekadensi moral, pada hakekatnya masyarakat dalam hidupnya akan menjadi kehilangan arah, berjalan tanpa jejak, meniti tanpa pegangan dan menapak kaki tanpa pijakan.

Maka dekadensi moral yang diderita oleh masyarakat dewasa ini adalah sebagian dari bobroknya dan hancurnya moral dan mental manusia, terutama 
dalam kehidupan remaja, maka dalam hal ini yang mendorong penulis untuk mengangkat permasalahan tersebutdengan judul "Peranan Pendidikan Agama Islam Dalam Mengatasi Dekadensi Moral (Studi Kasus Desa Melati II Kec. Perbaungan Kab. Deli Serdang).

Berdasarkan latar belakang di atas maka penulis memfokuskan penelitian ini dalam beberapa point yaitu

1. Untuk mengetahui bagaimana pelaksanaan kelompok-kelompok masyarakat Desa Melati II

2. Untuk mengetahui peranan pendidikan agama Islam ini dalam mengatasi dekadensi moral remaja, serta bagaimana pula pengaruhnya terhadap kehidupan masyarakat.

3. Untuk mengetahui apa saja penyebab terjadinya kebobrokan akhlak atau moral di kalangan Desa Melati II

4. Untuk mengetahui hambatan apa sajakah yang ditemui dalam pelaksanaan pendidikan agama untuk mengatasi dekadensi moral serta bagaimana penanggulangannya.

\section{KAJIAN PUSTAKA}

\section{A. Pendidikan Agama Remaja}

Dewasa ini, dimana perkembangan dan pertumbuhan sains dan teknologi makin maju, tentunya dalam hal ini harus sebanding dengan lajunya pendidikan dan perkembangan pendidikan agama, karena pendidikan agama salah satu usaha untuk membentuk kepribadian seseorang agar dapat memiliki sifat-sifat yang baik dan utama, berilmu, taat dan beramal.

Zuharaini (1983:27) mengatakan bahwa dalam hal ini sesuai dengan arti dan definisi dari pendidikan agama yaitu: "Usaha-usaha secara sistematis dan pragmatis dalam membantu anak didik agar supaya mereka hidup sesuai dengan ajaran Islam". ${ }^{14}$ Maka bilamana pendidikan agama ini tidak dapat dilaksanakan di tengah-tengah masyarakat dan dalam kehidupannya, jelaslah akan membawa kepada kemunduran atau kebobrokan moral remaja. 


\section{B. Pengertian dan Jenis-jenis Dekadensi Moral}

Kata dekadensi ini sering disebutkan oleh masyarakat, karena itu perlu untuk menguraikan pengertian tentang dekadensi ini. Dalam hal ini akan diungkapkan pendapat para ahli yang antara lain:

1. Poerwadarminta (1980:38) mengatakan bahwa "kata dekadensi dalam bahasa Inggersi, Kamus Lengkap Inggris Indonesia ditulis "Decadenci" dengan artinya: "kemunduran". Sedangkan di dalam bahasa Inggris juga ditulis "moral" yang artinya "kesopanan". Poerwadarminta (1980:118)

2. Poerbakawatja dkk (1982:69) mengatakan bahwa kata dekadensi itu dengan artinya "merosot, jatuh, turun".

Sedangkan yang dikatakan moral adalah:

1. Suatu istilah untuk menentukan batas-batas dari sifat-sifat, corakcorak, maksud-maksud, pertimbangan-pertimbangan, yang secara layak dapat dinyatakan baik, buruk, benar atau salah. Dalam hal ini lawannya amoral.

2. Suatu istilah untuk mengatakan bahwa yang baik / buruk dan benar itu lebih dari pada yang buruk / salah, lawannya in moral.

3. Nilai dasar dalam masyarakat untuk memilih antara nilai-nilai hidup (moral) juga adat istiadat yang menjadi dasar untuk menentukan baik/buruk.

4. Pada individu, unsur-unsur yang merupakan sifat-sifat kelakuan yang disebut baik/buru, yaitu sesuai dengan ukuran-ukuran yang diterima oleh seluruh kelompok dimana individu itu berada (morals). ${ }^{18}$ Poerbakawatja dkk (1982:219)

Dari uraian di atas, cukup jelas memberi pengertian dan pemahaman yang konkrit bagi kita, bahwa dekadensi moral itu adalah masalah kerusakan moral (akhlak) dan kelakuan yang disebut baik/buruk manusia. Uraian beberapa definisi tersebut di atas lebih jelas lagi bila dilihat apa yang telah diungkapkan oleh Meleh bahwa dekadensi moral adalah musuh utama bagi nusa dan bangsa/negara bahkan lebih utama 
dari kemiskinan dan kebodohan, dekadensi moral pada sutau bangsa bagaikan kanker mengganas di tubuh manusia menghancurkan segala potensi dan merenggut nyawanya.

Dengan keterangan tersebut maka dekadensi moral ini bagaimanapun harus ditanggulangi dari negara kita ini, khususnya di Desa Melati II, karena hal ini sangat mudah menular dan terdapat dimana -mana daerah, terlebih-lebih di kota-kota besar, bahkan telah merambat ke desa -desa dan menimpa generasi muda dan anak-anak belasan tahun yang diharapkan melanjutkan perjuangan bangsa, menuju era tinggal landas. Karena itu bila hal ini terus menerus berkembang tanpa adanya pencegahan dari berbagai pihak, tentu akan membawa dampak negatif yaitu kehancuran dan kemunduranlah bagi generasi yang akan datang, baik di kota -kota maupun di desa.

Adapun jenis-jenis dekadensi moral itu ada yang penulis ketahui di daerah lokasi penelitian yaitu Desa Melati II, dalam hal ini penulis mengadakan wawancara dengan Bapak Kepala Desa setempat dan beberapa orang tokoh masyarakat, yaitu Alkohol (minuman yang memabukkan), Ganja dan morphine, Judi, Perzinaan dan pelacuran

1. Alkohol (minuman yang memabukkan)

Yunus (1973:369) mengartikan alkohola berasal dari bahasa Arab yang katanya " alkhuhulu" artinya sesuatu yang mudah menguap. Sedangkan dalam kamus Marbawi juga ada dijelaskan yaitu "alkuhulu artinya pasti araq". Alkohol ini merupakan sejenis racun yang sangat berbahaya dan dapat pula meracuni sel-sel tubuh manusia dan juga dapat menimbulkan rangsangan sehingga si peminum dapat berulang kali meminumnya, hingga menjadi kebiasaan, jika tidak meminumnya sehari saja bisa rasa badan kurang enak/sehat, yang akhirnya menjadi ketagihan. Memang orang yangbaru -baru meminumnya tidaklah nikmat, tetapi karena pekerjaan itu berulang-ulang, akhirnya menjadilah kebiasaan yang menyenangkan dan mudah dikerjakan. 
Pengaruh urat syarat sangat erat hubungannya denga apa yang selalu dirasakan oleh manusia, atau suatu kebiasaan, seperti apa yang dijelaskan oleh Ya'cub (1987:53) menurut ilmu-ilmu jwa, segala apa yang dirasakan oleh manusia, erat hubungannya dengan urat syaraf dan otaknya". Alkohol juga dapat mendatangkan berbagi serangan penyakit pada tubuh manusia, Mustafa KS (1980:20) ada mengatakan: jika al-kohol diminum sekali saja berarti si peminumnya dibekali racun yang dengannya dapat daya tahan badan kurang mampu menolak serangan penyakit hingga mudah kejangkitan bermacam - macam penyakit."

Segala minuman keras atau yang dapat memabukkan ini dapat juga disebut khamar, khamar juga berasal dari bahasa Arab yaitu الخَ yang artinya "menutup". Yunus (1973:121)

Jadi segala sesuatu yang dapat memabukkan dapat digolongkan kepada khamar, sebagaimana yang dijelaskan oleh Nabi Saw.:

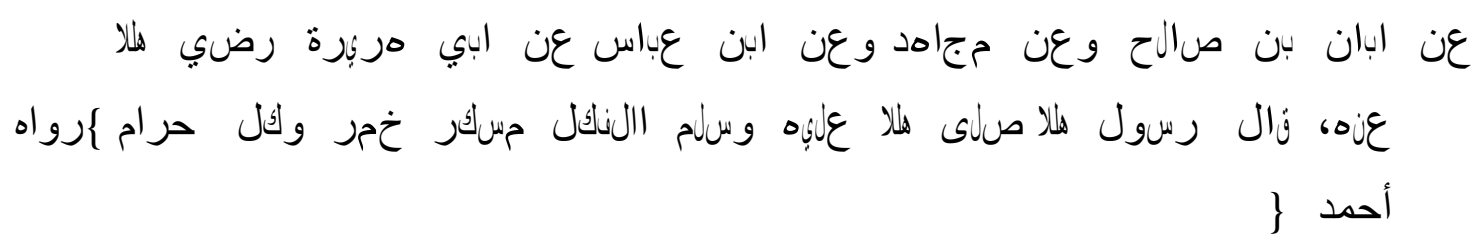

Artinya: Dari Aban ibn Salih dan dari Mujahid dari Ibnu Abbas dari Abu

Hurairah ra. bersabda saw. :"Ingatlah tiap-tiap sesuatu yang memabukkan itu adalah khamar dan tiap-tiap khamar itu haram".

Dengan demikian jelaslah bahwa segala yang memabukkan adalah termasuk khamar dan bahwa khamar berarti sesuatu yang dapat menutupi akal. Jadi bila akal tertutup, maka dengan mudahlah melakukan sesuatu yang melanggar norma agama dan norma-norma susila dan sekaligus dapat menimbulkan sifat-sifat yang amoral, seperti di zaman jahiliyah dahulu, di mana masyarakatnya sangat gemar meminum alkohol, besar, kecil, tua, muda, lelaki, perempuan, mereka sama-sama penyandu alkohol. Ternyata efek inilah yang menjadi sebab timbulnya dekadensi moral bagi bangsa. 
Maka akibat minuman keras ini, menjadi dampak positif menimbulkan sifat-sifat kebinatangan yang buas, tidak mengenal pri kemanusiaan, menghilangkan kesopanan dan kesabaran serta tidak lagi bermoral, apabila masyarakat tidak tampak lagi keunggulan moral dimana sopan santun akan hilang. Justru hal yang seperti itu agama tidak membiarkan manusia terus menerus dalam kerusakan, maka Allah perlu mengutus seorang Rasul untuk mencegah perbuatan yang menjadi kebiasaan bagi bangsa Arab.

Dept. Agama RI (1985:176) oleh karena pengaruh khamar ini sangat berbahaya, bahkan salah satu sumber kejahatan, maka agama sekaligus mengharamkannya. Seperti firman Allah Swt. dalam Al-Quran:

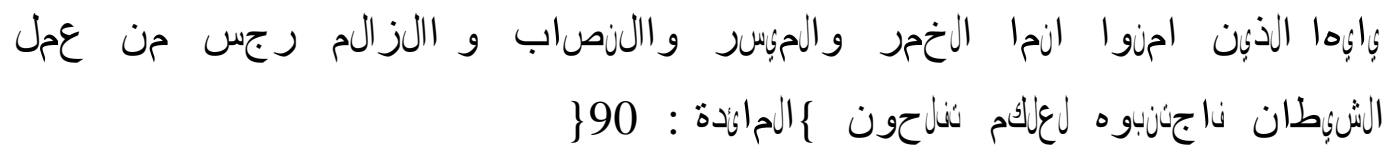

Artinya: Hai orang-orang yang beriman sesungguhnya khamar, judi, berhala dan undian-undian itu semua keji dari perbuatan syaitan, maka harus kamu tinggalkan semuanya supaya kamu mendapat kemenangan. ${ }^{26}$ Dengan penjelasan ayat ini, dapat dipahami bahwa khamar itu adalah perbuatan syaitan yang ingin mencelakakan manusia dari jalan kebenaran, maka dengan demikian jelaslah bahwa khamar itu mengandung alkohol dan dapat memabukkan, maka khamar salah satu sumber kejahatan.

2. Ganja dan morphine

Ganja juga salah satu faktor yang dapat merusakkan urat syaraf berpikir, pecandu ganja sama halnya dengan pecandu alkohol, juga biasanya sering dilakukan oleh anak-anak muda yang sedang prustasi, maka bila ia menghisap ganja, ia bisa tenang dan biasanya orang yang mabuk ganja ini persis orang gila, kadang-kadang ia ketawa dan bila memandang sinar matanya tajam dan sayu, maka ganja ini adalah sejenis tumbuh-tumbuhan yang memabukkan.

Badjamal dkk (1973:8) telah mengatakan dalam bukunya: "Ganja adalah suatu tumbuh-tumbuhan (cannabissativa) yang didapat di daerah tropis /sub tropis dan berasal dari Asia, kemungkinan dari 
Tiongkok". ${ }^{27}$ Bahan yang berasal dari tumbuh-tumbuhan ini, ada yang dihisap seperti rokok, ada yang dikunyah, dimakan atau dihirup. Tetapi pada masa sekarang ini yang paling banyak pemakaiannya ialah dihisap sebagai rokok, yaitu sering disebut rokok ganja.

Adapun morphine, yaitu bahan yang berasal dari buah tanaman papaver somnifrum yang dikeringkan, bahan sejenis morphine ini, terutama dibuat obat suntik, misalnya morphine injektion, pethidine injektion serta heroin injektion. Seribu tahun yang lalu di negeri Cina orang sudah tahu menggunakan tanaman ini untuk obat penenang dan untuk menghilangkan rasa nyeri, malah pada penyatatan Cina juga dulu juga menggunakannya untuk tambahan sebagai anasthesia operasi. Dan sekarang ini pemakaiannya bukanlah karena pengobatan seperti yang digunakan para dokter akan tetapi digunakan pemakaiannya sebagai pengobatan yang tidak ditentukan dokter, yang memakainya terutama di gank-gank (kumpulan) yang mempunyai tempat tertentu. Kadang-kadang pemakaian bahan ganja dan morphine ini biasanya dimulai dengan beberapa hal di antaranya:

a. Orang yang melarikan diri dari keadaan lingkungannya karena berharap dapat ketengan jiwa misalnya akibat konflik -konflik rumah tangga, percekcokan suami isteri, prustasi dan lain-lain.

b. Anak-anak muda yang bingung karena tekanan dari orang tua/keluarganya yang tidak bersifat mendidik dan kurang perhatian orang tua atau keluargaya, dan kegagalan-kegagalan yang dialami di sekolahnya, akibat tidak dapat ditanggulangi.

c. Orang yang mudah gugup, mudah gelisah, menggunakan bahan ini untuk berusaha menghilangkan sifat-sifat itu.

d. Adanya pengaruh kebudayaan asing yang sangat drastis menyelubungi kehidupan masyarakat, baik melalui film, turisturis, heppies-heppies, perjudian-perjudian serta bidang rekreasi yang kurang baik.

Adapun akibat dari pemakaian ganja dan morphine ini, adalah sangat besar bahayanya, bagi penghisap ganja dunia ini seperti tidak ada batas 
baginya, fungsi inteleknya tidak bertambah malah semakin rusak, segala norma uumu tidak berlaku, demikian juga sesuatu yang mengontroliperbuatannya hilang. Jadi tidak ada lagi hambatan dalam dirinya jika ia mengerjakan perbuatan-perbuatan yang diingininya.

3. Berjudi

Di antara faktor yang dapat mendorong orang sampai ke tingkat dekadensi moral yaitu judi, pada mulanya seorang yang melakukan perbuatan ini, masih dapat ditahan, akan tetapi oleh karena timbul hasrat hati ingin memiliki keuntungan tanpa bersusah payah, apalagi umpamanya seseorang yang mendapat kemenangan dalam permainan atau undian tersebut, hal ini akan membawa ketagihan hingga berulang kali melakukannya sampai ia berhasil, sekalipunn dengan tidak disadarinya bahwa hartanya telah habis, namun ia tetap berusaha untuk mengembalikannya. Judi adalah perbuatan yang terlarang dalam ajaran Islam, walaupun judi tersebut dapat memberi manfaat bagi manusia, akan tetapi dosa megerjakannya itu lebih besar lagi ketimbang manfaatnya. Seperti firman Allah Swt. dalam Al-Quran surat al-Baqarah ayat 219:

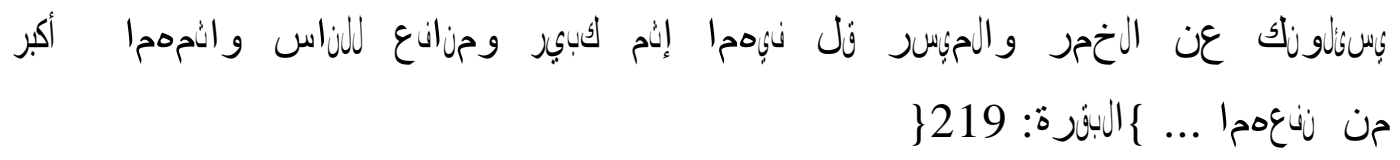

Artinya: Mereka bertanya kepadamu tentang khamar dan judi ketahuilah, pada keduanya itu terdapat dosa besar dan beberapa manfaat bagi manusia, tetapi dosa keduanya lebih besar dari manfaatnya.

Dalam ayat tersebut jelas dikatakan bahwa judi di samping ada kemanfaatannya, juga dosanya lebih besar lagi dari kemanfatannya. Ini berarti bahwa kemanfaatan yang sedikit sekali bukanlah apa -apa jika dibandingkan dengan kerusakannya, bahkan kemanfaatannya itu akanlenyap dikalahkan oleh kerusakan yang besar itu. ironisnya, judi bukan saja kerusakannya itu menimpa si pelaku tetapi terhadap keluarga, lingkungan masyarakat pada umumnya, sebab bila pelakunya mengalami kekalahan, maka tentu saja hasrat hatiny ingin untuk mengembalikannya, a khirnya ia terpaksa melaksanakan tindakan yang keji dengan jalan merampas, 
membunuh, melakukan berbagai kezaliman. Judi jika dilihat dari segi manfaatnya, misalnya uang kemenangan hasil judi bisa untuk berpoya -poya, untuk rilek dan lain sebagainya.

Namun, bila diperhatikan dalam ayat tersebut yang menyebutkan bahwa judi itu lebih besar kerusakannya (dosanya) ketimbang manfaat, ini dapat dilihat dari akibat negatif yang ditimbulkan dari judi itu, disini penulis akan mengemukakan beberapa akibat yang ditimbulkan dari judi antara lain:

a. Judi dapat merusak kesehatan akibat tidak kenal lelah, kurang tidur, kurang istirahat dan kurang makan karena tidak lagi diingatnya.

b. Judi dapat membawa permusuhan antara kawan sepermainan.

c. Judi dapat mengakibatkan malas bekerja akibat memikirkan untung, tidak lagi memikirkan rugi, ingin supaya lekas mendapat keuntungan yang besar tanpa bekerja keras.

d. Judi dapat membawa keretakan dan kehancuran rumah tangga, akibat kalah judi, bahkan banyak terjadi perceraian karenanya.

e. Judi dapat membawa kemiskinan dan kemelaratan, akibat kalah judi seluruh harta bisa terjual.

f. Judi dapat menghilangkan kesadaran, kadang-kadang sampai ada yang menjadi pencuri, perampok, penipuan, kemudian dipergunakan untuk berjudi.

g. Judi juga dapat mengakibatkan gila, akibat harga habis dan banyak lagi hal-hal yang negatif akibat perjudian itu.

4. Pelacuran dan Perzinaan

Disini penulis ingin menguraikan terlebih dahulu tentang pengertian pelacuran. Pelacuran dalam bahasa Inggris ditulis prostitutie (prostitusi) yang artinya perempuan pelacuran.

Menurut Abrahan Flexner dalam Samsyuddin (1996:101) yang dimaksud pelacuran ialah seorang perempuan yang secara tetap atau berkala mengadakan hubungan sexuil dengan laki-laki dengan tidak menurut aturan perkawinan yang sah, untuk 
memperoleh uang atau berdasarkan pertimbangan memperoleh keuntungan lainnya. Sedangkan yang dimaksud dengan perzinaan hanya sedikit saja perbedaannya yaitu: "Jika perzinaan tidak mengharapkan uang atau keuntungankeuntungan lainnya melainkan semata-mata untuk memuaskan nafsu sexuil yang bergelora.

Dari kedua defenisi ini dapat disimpulkan bahwa yang menjadi faktorfaktor penyebab timbulnya kejahatan yang bersifat pelacuran dan perzinaan ini tidak lain hanyalah masalah ekonomi, alasan-alasan ekonomi adalah merupakan pokok atau dasar dari timbulnya pelacuran, dan bahwa sebab pokoknya adalah kemiskinan, sedangkan pelacur -pelacur sendiri menerangkan bahwa kesulitan mencari penghidupan dengan cara lain adalah merupakan pekerjaan ini.

Maka pelacuran dan perzinaan ini adalah merupakan kemanusiaan yang tak pernah terselesaikan sampai ke abad modern ini, bahkan perbuatan keji seperti ini bukan lagi masalah individual kesukuan nasional atau internasional, akan tetapi sudah menyeluruh setiap lapisan bangsa dan masyarakat, terlebihlebih di dunia barat yang akhirnya manusia kehilangan moralnya. Hal ini dapat merusak keserasian hidup bersama, dan sebagai gejala terakhir dalam masyarakat kita, juga merupakan salah satu ciri kenakalan remaja. Justru karena itu dapat dilihat di lapangan kehi dupan masyarakat pelacuran, baik jasmaninya maupun rohaninya, apalagi terhadap negara kita yang sedang membangun sekarang ini, benar -benar tidak menunjang, pelacuran merusak moral bangsa dan dapat merusak generasi yang akan datang, bahkan masyarakat dan lingkungan dan dapat pula merusak kesehatan.

Adapun bahaya yang ditimbulkan dari pelacuran itu secara logis dan positif antara lain:

a. Pelacuran dapat menjadi sumber penularan penyakit kelamin atau yang sering didengar yaitu penyakit AIDS, oleh karena tidak semua pelacur dan para langganannya mengerti kesehatan, lebih - 
lebih pelacur tingkat rendah, maka adalah sumber penyakit kelamin yang dapat merusak kesehatan dan keturunan.

b. Pelacuran dapat merusak kehidupan rumah tangga, karena bila seorang suami senang mengunjungi tempat pelacuran, biasanya ia akan melalaikan kewajiban sebagai suami, tak mau memberi nafkah kepada isteri dan anak-anaknya, akibatnya anak dan isteri terlantar dalam hidupnya dan banyak yang terjadi perceraian karenanya.

c. Pelacuran dapat menimbulkan berbagai kejahatan, misalnya: mencuri, merampok dan sabagainya, karena mendatangi tempat pelacuran itu memerlukan uang dan pelacur-pelacur itu telah biasa hidup mewah, tentu jika tak punya uang terpaksa melakukan kejahatan itu dan di kalangan laki-laki sama laki-laki juga sering timbul rasa cemburu terhadap yang menginginkan pelacur langganannya, akhirnya timbullah perkelahian dan pembunuhan.

d. Pelacuran dapat menyebabkan adanya anak yang tidak sah. Anak yang lahir tak diketahui siapa ayahnya, sulit untuk menetapkan status hukumnya, sehingga sering terjadi peristiwa perkara di pengadilan yang sulit untuk dipecahkan, terutama dalam soal warisan dan banyak lagi hal yang ditimbulkan dari pelacuran dan perzinaan tersebut. Namun penulis tidak dapat menyebutkan keseluruhannya, akan tetapi nyatalah bahwa pelacuran dan perzinaan itu merusak kesusilaan dalam hidup dan moral, dan bila kerusakan moral ini pada suatu bangsa dapat menjadi sumber kehancuran dalam segala bidang.

\section{METHODE PENELITIAN}

\section{A. Lokasi Penelitian}

Penelitian ini dilaksanakan di desa Melati II Kecamatan Perbaungan Kabupaten Deli Serdang. Berdasarkan hasil wawancara penulis dengan Bapak Kepala Desa Melati II, diperoleh keterangan bahwa luas Desa Melati II \pm 550 ha, yang terdiri dari tiga dusun yaitu Dusun 1 Waringin, Dusun 2 Nangka, dan Dusun 3 Rambutan. Sedangkan batas-batasnya adalah sebagai berikut: 
- Sebelah Utara berbatas dengan Desa Tualang Kecamatan Perbaungan.

- Sebelah Selatan berbatas dengan Desa Melati I Kecamtan Perbaungan.

- Sebelah Timur berbatas dengan Desa Sitaman Jernih Kecamatan Perbaungan.

- Sebelah Barat berbatas dengan Desa Pengasahan Kecamatan Perbaungan.

\section{B. Sumber Data}

Untuk mempermudah peneliti memperoleh data dan keterangan, maka sumber data dalam penelitian ini dibagi dua bagian, yaitu:

1) Data Primer, yaitu data pokok yang diperoleh dari kelompok-kelompok remaja, orang tua dan masyarakat umumnya.

2) Data Skunder, yaitu data yang diperoleh dari Kepala Desa Pemukapemuka agama yang ada di desa tersebut.

\section{Teknik PengumpulanData}

Untuk menghimpun data yang dibutuhkan dalam penelitian ini digunakan berbagai alat sesuai dengan penelitian,yaitu:

1) Observasi, yaitu penulis langsung terjun ke lapangan lokasi penelitian yaitu masyarakat Desa Melati II.

2) Interview (wawancara) yaitu mengadakan tanya jawab kepada informal dan non formal baik dari kalangan remaja, orang tua dan pemuka-pemuka masyarakat yang dianggap lebih mengetahui tentang masalah ini.

3) Penelitian perpustakaan (library research) yaitu mengadakan studi pada beberapa buah buku yang berkaitan dengan masalah yang akan dibahas, kemudian mengaitkan dengan permasalahan yang ditemui di lapangan.

\section{HASIL PENELITIAN DAN PEMBAHASAN}

\section{A. Hubungan Pendidikan Agama dengan Kehidupan Remaja}

Islam merupakan suatu agama yang ditujukan bukan untuk suatu golongan tertentu, melainkan untuk semua ummat manusia dalam upaya menjadikan remaja mendapat kebahagiaan dunia dan akhirat. oleh karena itu agama Islam menuntut kepada setiap pemeluknya untuk mempelajari serta menggali ajaran-ajaran yang terkandung di dalamnya. Sebab agama juga adalah pandangan hidup remaja dalam arti yang sebenarnya, dan satu kekuatan yang cukup ampuh untuk menjadi landasan moralitas dan kontrol sosial yang baik, sehingga demikian agama menjadi sangat perlu ketika suatu bangsa sedang menjalankan modernisasi dan 
pembangunan, maka sudah sewajarnyalah pendidikan agama itu lebih ditingkatkan, terutama terhadap generasi muda yang akan hidup di masa akan datang, supaya tercipta kondisi-kondisi sosial yang baik, agar di kemudian hari dapat menjadi bangsa yang maju dengan tetap berindentitaskan diri sebagai bangsa yang beriman bermoral, beragama dan tahu tentang arti hidup yang sebenarnya. Pada sisi lain agama itu merupakan kebutuhan manusia, karena beragama pada hakekatnya merupakan fitrah dari diri manusia, karena manusia sejak lahir sudah dibekali naluri beragama.

Kalau kebutuhan fitrah manusia ini diingkari, maka nampaklah hidup manusia akan mengalami kekeringan jiwa dan kekosongan batin. Satu hal terjadi ketika kehidupan makin maju, bahwa manusia makin ditekan oleh lingkungan hidupnya yang materialistis, yang akhirnya terjadilah dekadensi moral, hidup tanpa agama akan mengalami kebingungan, keresahan dan ketidaktentraman. Terintegrasinya ajaran Islam ini ke dalam jiwa manusia, manakala ajaran Islam itu dijadikan bagian dari kehidupannya.

Bangsa Indonesia merupakan suatu bangsa yang beraneka ragam kepercayaannya, budaya, dan agama. Team Pembina Penataran (1981:154) mengatakan:

Bangsa Indonesia menghendaki keselarasan hubungan antara manusia dengan Tuhannya, antara sesama manusia serta lingkungan alam sekitarnya, keselarasan hubungan antara bangsa -bangsa dan keselarasan cita-cita hidup di dunia dan mengejar kebahagiaan di akhirat. $^{32}$

Sebab itu umat Islam yang benar-benar memahami agamanya tidak pernah ragu dan tak pernah mengalami kebimbingan dalam mewujudkan kesatuan di tengah-tengah masyarakat, oleh karena itu, agama Islam adalah merupakan suatu agama yang dapat mengatur kehidupan bermasyarakat, bernegara dan berbangsa.

Hamka (1941:93) adapun tanda agama yang benar dan hak itu: itulah dapat menghidupkan dan menyadarkan serta menginsafkan di dalam hatimu perasaan tahu akan harganya hidup ini, agama yang tidak menimbulkan putus asa tetapi mengajarmu menjadi manusia yang 
tahu akan harga diri dan memberi merdeka pula pada orang lain buat berlaku menurut timbangannya serta akan kewajibannya.

Kita telah membaca bahwa sejarah Nabi-nabi menunjukkan, setiap Nabi dan Rasul diutus oleh Allah pada prinsipnya adalah untuk memperbaiki kehidupan suatu kaum tertentu yang telah rusak, baik keyakinan maupun pandangan hidupnya, moralitas ataupun tantangan hidupnya dan sosialnya, dan ternyata dalam hal ini sejarah manusia tidak cukup hanya dengan seorang Nabi untuk memperbaiki kehidupan ini membuktikan bahwa manusia mempunyai pola pikir kecenderungan hidup yang mengarah kepada kesesatan dan kerusakan. Maka kerasulan Nabi Muhammad Saw. diutus di tengah-tengah masyarakat Jahiliyah membawa misi memperbaiki kebobrokan moral dan kesesatan akidah.

\section{B. Peranan Pendidikan Agama dalam Pembinaan Moral}

Kondisi moral memang sangat menentukan dalam segi kehidupan, terlebih-lebih dalam lingkungan masyarakat, hanya orang baik moralnya yang dapat merasakan bahagia dalam hidupnya, maka agama sumber utama dalam membina hidup mampu mengendalikan gelombang kehidupan yang serba kritis, hanya dengan agamalah hidup menjadi aman, tidak resah dan tentram. Maka justru karena itu agama Islam yang dibawa Nabi Muhammad Saw. terutama yang menjadi sasaran adalah pembinaan akidah dan akhlak, maka pembinaan akhlak atau moral ini sejak anak masih kecil. Agama masuk menjadi unsur-unsur yang menentukan kosntruksi pribadi sejak kecil, oleh sebab itu bila seseorang menjadi dewasa tanpa mengenal agama, maka kegoncangan jiwanya akan mengarah ke sifat yang amoral. Maka agama secara intensif pula memberikan petunjuk ke arah pembinaan akhlak atau moral.

Agama masuk menjadi unsur-unsur yang menentukan kosntruksi pribadi sejak kecil, oleh sebab itu bila seseorang menjadi dewasa tanpa mengenal agama, maka kegoncangan jiwanya akan mengarah ke sifat yang amoral. Maka agama secara intensif pula memberikan petunjuk ke arah pembinaan akhlak atau moral. Firman Allah Swt.: 


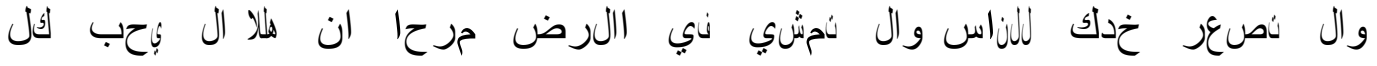

مخنال نخور

Artinya:

Dan janganlah kamu memalingkan muka dari manusia (karena sombong) dan jangan kamu berjalan di muka bumi dengan angkuh, sesungguhnya Allah tidak menyukai orang-orang yang sombong lagi membanggakan diri.

Agama berfungsi sebagai terapi bagi jiwa yang goncang dan obat bagi masyarakat, juga berperan sebagai alat pencegah (preventif) terhadap kebobrokan moral dan merupakan faktor pembina (konstruktif) bagi manusia ke jalan yang lurus. Maka dengan keyakinan hidup beragama hidup menjadi dekat kepada Tuhan serta menjamin kehidupan masyarakat yang bermoral.

\section{Urgensi Pembinaan Pendidikan Agmaa di Kalangan Remaja}

Sebagaimana telah diuraikan pada uraian terdahulu, bahwa agama merupakan dasar yang sangat urgen bagi kehidupan, terlebih-lebih bagi kaum remaja, jika diibaratkan sebuah bangunan, maka agama merupakan fondamennya dan moral adalah keindahan bangunan itu. apabila sendi itu kuat, niscaya bangunan yang ada di atasnya berdiri indah dan megah. Sebaliknya jika bangunan sendinya tidak kuat, maka pasti bangunan yang ada di atasnya akan goyang dan ambruk.

Akhlak atau moral sangatlah urgen bagi manusia, urgensi akhlak atau moral ini tidak saja dirasakan oleh manusia dalam kehidupan perseorangan tetapi juga dalam kehidupan berkeluarga dan bermasyarakat, bahkan tidak kurangkurangnya juga dirasakan dalam kehidupan berbangsa dan bernegara. Kehidupan dengan ilmu pengetahuan saja belum cukup. Kekacauan dan kejahatan tidak bisa diobati dengan ilmu, sebab yang menyebabkannya memang bukan karena kurangnya ilmu, melainkan karena kurangnya akhlak. Meskipun tiap-tiap manusia dan bangsa itu menghajatkan kepada ilmu pengetahuan, akan tetapi kepada akhlak atau moral mereka lebih menghajatkan. 
Farid Ma'ruf mengatakan sebagaimana telah kita ketahui bahwa bila timbul penyakit dalam lingkungan masyarakat, sangat dihajatkan ilmu kedokteran untuk mengurangi dan melenyapkan penyakit itu, dan menyelematkan manusia dari bahaya akan menimpanya. Demikian pula bila timbul gejala-gejala keburukan dalam golongan manusia, terasa benarlah kebutuhan kita kepada ilmu akhlak atau moral untuk mengobati jiwanya dan membersihkan dari bahaya keburukan yang mengancamnya.

Moral adalah pembela keutamaan dan penentang keburukan. Keutamaan itu tidak akan terwujud, kecuali dengan melakukan kewajiban, dan orang utama itu bukan karena hanya mengetahui apa yang harus dilakukan, akan tetapi dia dikatakan orang utama, karena ia melakukan kewajiban dan meninggalkan apa yang harus ditinggalkan. Remaja adalah merupakan generasi yang akan menentukan nasib suatu bangsa yang akan datang. Namun mereka harus dibekali agama dan bermoral tinggi. Agama adalah kebutuhan psykhis (rohani) dan fisik (jasmani) dan akhlak atau moral adalah pakaian dan perhiasannya, yang dengannya lahir kebaikan-kebaikan dan kebahagiaan.

\section{Berbagai Macam Tantangan dan Usaha Penanggulangan}

Sudah dibicarakan pada uraian pada pasal terdahulu, sesungguhnya masalah dekadensi moral ini mendapat perhatian dari masyarakat dan juga pemerintah, namun masalah ini bila ditanggulangi merusak ketentraman masyarakat dan kehancuran hari depan remaja, maka berkenaan dengan masalah ini penulis akan menguraikan usaha yang dilalui masyarakat Desa Melati II dalam penanggulangan dekadensi moral ini. Penulis berpendapat bahwa usaha penanggulangan dekadensi moral ini dan sekaligus pembentukan kepribadiannya, oleh masyarakat Desa Melati II dengan Pendidikan agama di sekolah, Pendidikan agama di rumah tangga, Pendidikan agama di masyarakat

Adapun ruang lingkup pendidikan agama, tidak terbatas kepada ibadah shalat, puasa, mengaji dan sebagainya, sehingga ada orang mengatakan bahwa pendidikan agama Islam itu ritual, padahal tidak 
demikian, akan tetapi pendidikan agama ini sangat luas yang universal, baik ibadah, muamalah dan akhlak, maka pembinaan jiwa agama adalah paling dominan, sejak dini membiasakan hidup sesuai dengan nilai-nilai agama.

Barnadib (1985:72) anak-anak memerlukan tuntunan yang teguh sesuai dengan tujuan pendidikan yang hendak dicapai. Hal in perlu karena anak harus diangkat keatas, supaya unsur-unsur atau gerak anak itu selalu berada di atas bentuk dan tujuannya.

Orang tua berkewajiban membimbing anak sejak lahirnya ke arah hidup yang sesuai dengan ajaran agama, agar si anak mengenal agama dalam kehidupannya. Dalam pendidikan agama orang tua adalah pendidik pertama untuk menanamkan jiwa agama kepada anak. Demikianlah pendidikan agama ini harus dibiasakan di dalam rumah tangga agar jiwa anak benar-benar mengenal agama. Nabi Muhammad Saw. menjelaskan betapa pentingnya pembiasaan itu anak sejak berumur tujuh tahun disuruh shalat, ini merupakan pembiasaan sejak kecil, hingga perintah shalat yang merupakan dasar ini sudah dalam jiwa anak.

\section{PENUTUP}

Berdasarkan uraian-uraian yang telah disajikan secara terperinci yaitu pada bab terdahulu, selanjutnya penulis mengambil beberapa kesimpulan yang diiringi dengan penyampaian saran-saran yang telah diambil dari uraian-uraian terdahulu, yaitu:

1. Pendidikan agama di Desa Melati II dilaksanakan oleh kelompok kelompok masyarakat yang terdiri dari pengajian kaum bapak, pengajian kaum ibu, dan pengajian remaja yang diadakan seminggu 3 kali di masjid maupun di rumah-rumah.

2. Ada dua faktor penyebab timbulnya dekadensi moral, yaitu Faktor intern yaitu kurangnya kasih sayang ibu bapak terhadap anaknya, suasana rumah tangga yang kurang aman dan minimnya pendidikan agama dalam lingkungan keluarga. Faktor ekstern yaitu pengaruh yang datang dari lingkungan yang kurang baik serta pengaruh kebudayaan asing yang bertentangan dengan norma -norma agama. 
3. Kehidupan tanpa agama pasti akan mendatangkan malapetaka seperti kegoncangan dalam hidup, tidak aman dala m lingkungan dan akan membawa kepada krisis moral. Segala sesuatu yang dilarang agama meminumnya dan dapat menghilangkan akal seperti minuman keras, ganja, dan morphin dan pengaruh judi, hal ini dapat membawa krisis moral.

4. Mengamalkan ajaran-ajaran agama adalah suatu hal kewajiban bagi umat Islam untuk mendapatkan ketengan dalam hidupnya di dunia dan untuk mencapai kebahagiaan di akhirat. Usaha -usaha yang dilaksanakan dalam menanggulangi dekadensi moral antara lain harus lebih meningkatkan mutu pendidikan agama baik di lingkungan keluarga, sekolah dan masyarakat.

\section{DAFTAR PUSTAKA}

Al-Marbawi Idris. 2000. Arab Melayu. Mesir: Mustafa al-al-Babi al-Halabi, Jilid II, 1354

Badjamal Mohd. Abd. Hafid dan Moh. Saleh Alkatiri. 1973. Ganja dan Morphine. Surabaya: FA Pustaka Prosesif

Bahresy Salim. 1999. Irsyadul Ibad Ila Sabilirrasyad. Surabaya: Darussaqaf

Barnadib Imam. 1985. Filsafat Pendidikan. Yogyakarta: IKIP

Departemen Agama RI. 1985. Al-Quran dan Terjemahannya. Jakarta: PT. Bumi Restu

Departemen Agama RI. 1985. Al-Qur'an dan Terjemahnya. Jakarta: PT. Bumi Restu

Drajat Zakiah. 1975. Pembinaan Remaja., Jakarta: PT. Bulan Bintang

Drajat Zakiah. 1982. Pendidikan Agama Dalam Pembinaan Mental. Jakarta: PT. Bulan Bintang

KS Mustafa. 1980. Alkohol dalam Pandangan Islam dan Ahli-ahli Kesehatan. Bandung: PT. Al-Ma'arif Cetakan I

Meleh Abdullah Said Basy. 2000. Missi Kemanusiaan. PT. Bina Ilmu

Poerbakawatja Soegarda, H.A. Harahap.1982. Ensiklopedi Pendidikan. Jakarta: Gunung Agung

Poerwadarminta Wojowasito W.J.S. 1980. Kamus Lengkap Inggris Indonesia, Indonesia Inggris. Bandung

Syamsuddin. 1996. Pendidikan Kelamin dalam Islam. Solo: CV. Ramadhani 
JISA: Jurnal Ilmiah Sosioologi Agama Prodi Sosiologi Agama Fakultas Ilmu Sosial UIN SU Medan Vol.2, No.2, November Tahun 2019

Ya'cub Hamzah. 1978. Ethika Islam. Jakarta: CV. Publicita

Yunus Mahmud. 2013. Kamus Arab Indonesia. Jakarta: Cetakan I

Zuharaini H. 1983. Methodik Khusus Pendidikan Agama. Surabaya: PT. Usaha Nasional 